\title{
SELF MANAGEMENT CONCEPT DALAM KEPEMIMPINAN
}

\section{LEMBAGA PENDIDIKAN}

\section{Syamsuriadi $^{1}$}

\begin{abstract}
Self-management concept is a leadership concept needed by leaders in educational institutions. In this context, self-management concept directs a leader of an educational institution to change attitudes, improve self-image, continue to work and work, maintain physical health, improve mind power, develop spiritual life, do things now, be consistent in learning, develop networks, build and maintain relationships, develop others by developing reasons why it is necessary to build others, empower others and create leaders, and build groups to grow together so as to ensure a conducive climate in educational institutions.
\end{abstract}

Keywords: Self-Management Concept, Leadership, Educational Institutions

\section{PENDAHULUAN}

Manusia merupakan makhluk sosial yang memiliki keterkaitan erat dengan manusia lain yang ada di lingkungan sosialnya. Disadari atau tidak, interaksi sosial yang terjadi di antara manusia tersebut memiliki suatu keterkaitan sistemik dimana baik atau tidaknya suatu tindakan sosial yang dilakukan oleh seseorang berimplikasi pada orang lain yang dalam bahasa sederhananya adalah kewajiban seseorang bisa menjadi hak bagi orang lain sementara hak seseorang menjadi kewajiban bagi yang lainnya.

Dalam interaksi sosial tersebut, kepemimpinan merupakan suatu hal yang memainkan peran strategis dalam mengarahkan semua komponen dalam sturuktur sosial termasuk dalam lembaga pendidikan. Dalam konteks keterkaitan antara self-management concept dengan kepemimpinan, dapat dipahami bahwa self-management concept mencakup seluruh pandangan individu akan dimensi fisiknya, seperti karakteristik pribadi, motivasi, kelemahan, kepandaian, dan lain sebagainya. Self-management concept dalam hal ini merupakan pandangan pengetahuan atau evaluasi mengenai diri sendiri yang

\footnotetext{
${ }^{1}$ Dosen Program Studi Manajemen Pendidikan Islam Institut Agama Islam Negeri (IAIN) Bone.
} 
mencakup dimensi fisik, karakteristik, pribadi, kelebihan dan kelemahan yang berpengaruh terhadap tingkah laku individu. ${ }^{2}$

Self-management concept dalam kepemimpinan lembaga pendidikan merupakan suatu konsep kepemimpinan lembaga pendidikan yang diharapkan mampu menciptakan suatu iklim lembaga yang kondusif karena terdistribusinya hak dan kewajiban secara proporsional.

\section{PEMBAHASAN}

\section{Self-Management Concept}

Self-managemen concept merupakan suatu konsep pemahaman diri yang memiliki relevansi dengan kemampuan seseorang memposisikan dirinya sebagai seorang individu dalam suatu struktur sosial. Prijosaksono, Aribowo dan Marlan Mardianto menggambarkan bahwa self-management concept terbangun atas 12 komponen yang dalam hal ini adalah:

a. Mengubah sikap dengan cara memperlakukan sesama seperti memperlakukan diri sendiri, mempercayai bahwa pasti ada peluang dalam setiap kesulitan, memandang bahwa hari ini adalah hari yang dijadikan Tuhan buat manusia, mengatasi musuh terbesar diri sendiri, serta jtidak ikut-ikutan pedulikan pendapat orang lain.

b. Memperbaiki pencitraan diri dengan cara mengenali siapa diri sendiri, mengatasi citra diri yang buruk, membentuk citra diri yang positif, serta menjadi sahabat bagi diri sendiri.

c. Terus bekerja dan berkarya dengan cara mempunyai prinsip dalam bekerja, bekerja dengan penuh rasa cinta, memiliki kegigihan dalam usaha serta bersifat proaktif.

d. Memelihara kesehatan fisik dengan cara mengenali kondisi fisik diri sendiri, melatih diri dengan cara berolah raga, serta memperhatikan makanan yang dimakan, serta menghindari kebiasaan buruk yang merusak.

e. Meningkatkan daya pikiran dengan cara tidak menyia-nyiakan kekuatan pikiran dengan mengenal otak dan pikiran, memahami bahwa alam bawah sadar merupakan kekuatan maha dahsyat, relaksasi sebagai jalan menuju alam bawah sadar, serta menciptakan realitas baru.

\footnotetext{
${ }^{2}$ Binti Mudkhiyyatul Ummah, Konsep Diri, http://mudkhiya.blogspot.com. (13 Juli 2019).
} 
f. Mengembangkan kehidupan spiritual dengan cara mengenal dan menemukan Tuhan, meditasi, memelihara dan mengembangkan kehidupan spiritual, merasakan kehadiran Tuhan setiap hari.

g. Melakukan sesuatu sejak sekarang dengan cara memulai langkah pertama, menentukan arah hidup serta berupaya disiplin terhadap jadwal yang telah ditentukan.

h. Konsisten dalam belajar dengan cara fokus pada melalui pendidikan dan pembelajaran, meningkatkan kemampuan membaca, menggunakan bahasa dan komunikasi, mengembangkan keterampilan, serta menerapkan kaizen dengan penyempurnaan berkesinambungan

i. Mengembangkan jaringan dengan cara mengetahui fungsi dari suatu jaringan, melatih seni membangun jaringan, serta memelihara jaringan

j. Membangun dan memelihara hubungan dengan cara saling mencintai sesama manusia, berkomunikasi empatik, mengatasi sakit hati, bersinergi dan kerja sama

k. Membangun sesama dengan cara mengembangkan alasan mengapa perlu membangun sesama, memberdayakan sesama serta menciptakan pemimpin.

1. Membangun kelompok tumbuh bersama dengan cara membentuk kelompok bersama, menyelenggarakan pertemuan kelompok, memelihara keutuhan kelompok, serta duplikasi kelompok. ${ }^{3}$

Kepemimpinan lembaga pendidikan merupakan suatu faktor penentu dari kesulsesan suatu lembaga pendidikan. Hal ini didasarkan pada pandangan Cooper dan Sawot, sebagaimana dikutip oleh Priyadharma bahwa kepercayaan diri adalah kekuatan emosi yang didasarkan atas rasa harga diri dan makna diri. Semakin besar rasa percaya diri, semakin besar peluang untuk mencapai keberhasilan dalam segala aktivitas. ${ }^{4}$

\section{Konsep Kepemimpinan Lembaga Pendidikan}

Eksistensi suatu lembaga pendidikan tidak bisa dipisahkan dari posisi pemimpin yang menjadi top-manager dalam pengambilan berbagai keputusan strategis dalam upaya memaksimalkan semua potensi yang ada dalam lembaga dalam mencapai visi kelambagaan yang telah ditetapkan. Menyikapi hal ini, Imam Munawir bahwa seorang

\footnotetext{
${ }^{3}$ Prijosaksono, Aribowo dan Marlan Mardianto, 12 Langkah Manajemen Diri, (Jakarta : Elex Media Computindo, 2001), h. 12.

${ }^{4}$ Triguna Priyadharma, Kreativitas dan Strategi, (Jakarta: Golden Trayon Press, 2001), h. 18.
} 
pemimpin yang berpotensi untuk mampu melakukan penguatan visi kelembagaan, paling tidak, harus memiliki beberapa karakter sebagai berikut:

a. Berpengetahuan. Seorang pemimpin harus memiliki kemampuan dalam bidang yang dipimpinnya dan mengetahui seluk-beluk bidang kegiatannya, baik dari dalam ataupun dari luar.

b. Memiliki keberanian dan inisiatif. Keberanian merupakan kemampuan batin yang mengakui adanya rasa takut tapi mampu menghadapinya dengan tenang. Dalam konteks tersebut, pemimpin harus menjadi pengayom dan pelindunjg sehingga para bawahannya merasa terlindungi dengan kehadirannya. Selain keberanian, pemimpin juga harus mempunyai inisiatif yang merupakan kemampuan untuk bertindak meskipun tidak ada perintah yang didukung oleh berbagai pertimbangan guna perbaikan tugas kepemimpinan yang diembangnya.

c. Tegas, bijaksana, adil, dan taat. Tegas adalah kesanggupan untuk mengambil keputusan dengan tegas apabila dibutuhkan ketegasan bersumber dari keyakinan dan kepercayaan diri seorang pemimpin. Bijaksana adalah kecakapan untuk bergaul dengan bawahan ataupun atasan dengan cara yang tepat diserta dengan pengambilan keputusan secara bijak. Kebijaksanaan merupakan kemampuan untuk menghargai, kapan harus bertindak, kapan harus diam, dan kapan harus menjadi pendengar. Adil berarti tidak memihak dan henya berkomitmen pada kebenaran. Adapun taat dapat diartikan sebagai kepatuhan terhadap keputusan yang telah disepakati dimana setiap keputusan bersama dijalankan secara konsekuen.

d. Mempunyai pembawaan yang baik, semangat yang besar, dan memiliki keuletan. Dalam implementasinya, pembawaan yang baik merupakan penjelmaan empirik dari isi diri yang harus dimiliki oleh seorang pemimpin. Pemimpin harus memiliki hasrat besar dan perhatian yang mendalam terhadap tugas yang dihadapinya serta ulet dalam menyelesaikan tugas-tugas tersebut.

e. Tidak mementingkan diri sendiri dan dapat menguasi diri sendiri. Seorang pemimpin tidak boleh mengambil keuntungan sendiri dari pekerjaan kelompok dalam organisasi yang dipimpinnya. Adapun dalam kaitannya dengan kemampuan menguasai diri sendiri, seorang pemimpin harus mengontrol diri dalam kepemimpinannya termasuk dalam komitmen yang telah dibangun bersama. 
f. Bertanggung jawab, ikhlas, dan bisa menjalin kerjasama yang baik. Seorang pemimpin akan berhasil dengan baik apabila memikul tanggung jawab atas kebijakan kepemimpinannya. Di samping itu, seorang pemimpin harus mempunyai jiwa yang ikhlas yang tidak hanya menuntut imbalan semata dengan kata lain pemimpin harus mencari ridha Allah swt. tanpa menghilangkan sisi profesionalitasnya. Kemampuan dalam menjalin kerjasama yang baik bisa dipahami sebagai kemampuan seorang pemimpin dalam memahami kehendak dan kemampuan bawahannya sehingga dia mampu membangun prinsip kerjasama yang baik dengan mereka.

g. Dapat menguasai persoalan secara terperinci dan menaruh simpati serta pengertian. Persoalan yang dimaksud adalah persoalan yang menyangkut posisinya sebagai seorang pemimpin. Pemimpin harus mampu berkomunikasi dengan bawahannya karena dengan komunikasi yang baik maka berbagai persoalan dapat dipahami oleh bawahannya yang. Hal ini pada akhirnya akan membuat bawahan menjadi simpati terhadapnya dan memiliki pengertian tentang kepemimpinannya. ${ }^{5}$

Pada dasarnya, Rasulullah saw sebagai suri tauladan dalam kehidupan umat Islam telah menjadi suatu miniatur historis yang memberikan keteladanan terkait dengan konsep kepemimpinan itu sendiri. Keteladanan Rasullah saw dalam hal kepemimpinan telah digambarkan oleh Muhammad Syafi'i Antonio bahwa Rasulullah saw merupakan sosok pemimpin yang telah berhasil membawa gerbong masyarakat Islam menuju stasiun peradaban umat manusia. Visi kepemimpinan beliau diwarnai dengan visi kepemimpinan yang sifatnya menyeluruh (holistic), diterima (accepted), serta teruji (proven). Visi kepemimpinan yang sifatnya menyeluruh (holistic) terbukti dari kemampuan beliau dalam mengembangkan kepemimpinan yang visioner dalam segala bidang di antaranya pengembangan diri (self-development), kewirausahaan (entrepreneurship), kehidupan rumah tangga yang harmonis, sisitem politik yang bermartabat, sistem pendidikan yang mencerahkan, sistem hukum yang berkeadilan, serta strategi pertahanan militer yang jitu, visi kepemimpinan yang sifatnya diterima (accepted) terbukti dari fakta sejarah bahwa kemampuan beliau dalam hal kepemimpinan telah diakui oleh 1,3 miliar manusia, serta visi kepemimpinan yang sifatnya teruji (proven) terbukti bahwa kepemimpinan beliau tetap

${ }^{5}$ Imam Munawir, Asas-Asas Kepemimpinan dalam Islam, (Surabaya: Usaha Nasional, tt.), h. 169- 
diakui efektivitasnya dalam mengakselerasi peradaban manusia sejak kurang lebih dari 15 abad yang lalu sampai hari ini. ${ }^{6}$

Dalam upaya melakukan penguatan visi kelembagaan perguruan tinggi keagamaan Islam, Burt Nanus menggambarkan bahwa pemimpin memiliki empat peran yang harus dijalankan dalam kepemimpinannya yaitu:

a. Peran penentu arah (direction setter). Peran ini merupakan peran dimana seorang pemimpin menyajikan suatu visi, meyakinkan gambaran atau target untuk suatu lembaga pendidikan untuk diraih pada masa depan. Dalam studi dan praktik kepemimpinan, hal ini dianggap sebagai esensi dari kepemimpinan. Sebagai penentu arah, seorang pemimpin menyampaikan visi, mengkomunikasikannya, memotivasi pekerja dan rekan, serta meyakinkan bahwa apa yang dilakukan merupakan suatu hal yang benar, serta mendukung partsipasi untuk seluruh tingkat dan seluruh tahap usaha menuju masa depan.

b. Agen perubahan (agent of change). Agen perubahan merupakan suatu peran penting yang kedua dari seorang pemimpin. Dalam konteks perubahan, lingkungan eksternal diposisikan sebagai pusat ekonomi, sosial, teknologi, dan perubahan politis terjadi secara terus menerus, beberapa berlangsung secara dramatis, dan yang lainnya berlangsung secara perlahan.

c. Juru bicara (speakperson). Memperoleh pesan keluar dan juga berbicara sehingga boleh dikatakan bahwa pemimpin dengan kepemimpinan visioner yang dimilikinya boleh dikatakan sebagai bagian dari proses memimpikan masa depan suatu organisasi. Seorang pemimpin visioner juga merupakan orang yang menghargai segala bentuk komunikasi tersedia sehingga dapat menjelaskan dan membangun dukungan untuk suatu visi masa depan.

d. Pelatih (coach). Pemimpin visioner yang efektif harus mampu menjadi pelatih yang baik. Hal ini mengisyaratkan bahwa seorang pemimpin harus menggunakan kerjasama kelompok untuk mencapai visi yang dinyatakan. ${ }^{7}$

${ }^{6}$ Muhammad Syafi'i Antonio, Muhammad Saw: The Super Leader, The Super Manager, (Jakarta: Tazkia Publishing, 2009), h. 6-7.

7 Burt Nanus, Terj. Frederik Ruma, Visionary Leadership: Creating a Compelling Sense of Direction for your Organization, (Jakarta: PT.Prenhallindo, 2001), h. 15-18. 


\section{Self-Management Concept dalam Kepemimpinan Lembaga Pendidikan}

Keberadaan self-management concept dalam kepemimpinan lembaga pendidikan merupaka suatu keniscayaan. Menyikapi hal tersebut, Husaini Usman menggambarkan bahwa ada 13 karakteristik mutu yang bisa menjadi suatu barometer dalam melihat bermutu atau tidaknya lembaga pendidikan seperti perguruan tinggi keagamaan Islam yang dalam hal ini meliputi:

a. Kinerja (Performa): Berkaitan dengan aspek fungsional perguruan tinggi, misalnya: kinerja dosen dalam mengajar baik, memberikan penjelasan meyakinkan, sehat dan rajin mengajar, dan menyiapkan bahan pelajaran lengkap. Pelayanan administratif dan edukatif perguruan tinggi baik yang ditandai hasil belajar tinggi, lulusannya banyak, putus kuliah sedikit, dan yang lulus tepat waktu banyak. Akibat kinerja yang baik maka sekolah tersebut menjadi perguruan tinggi favorit.

b. Waktu wajar (Timeliness): Selesai dengan waktu yang wajar, misalnya memulai dan mengakhiri pelajaran tepat waktu. Waktu ulangan tepat. Batas waktu pemberian pekerjaan rumah wajar. Waktu untuk dosen naik pangkat wajar.

c. Handal (Reliability): Usia pelayanan prima bertahan lama, misalnya: pelayanan prima yang diberikan perguruan tinggi bertahan dari tahun ke tahun, mutu perguruan tinggi tetap bertahan dari tahun ke tahun. Sebagai perguruan tinggi favorit bertahan dari tahun ke tahun. Perguruan tinggi menjadi juara tertentu bertahan dari tahun ke tahun. Dosen jarang sakit. Kerja keras dosen bertahan dari tahun ke tahun.

d. Daya tahan (Durability): Tahan banting, misalnya: meskipun krisis moneter, perguruan tinggi masih tetap bertahan, tidak tutup. Dosen dan mahasiswa tidak putus asa dan selalu sehat

e. Indah (Aesthetics). Misalnya eksterior dan interior perguruan tinggi ditata menarik. Taman ditanami bunga dan terpelihara dengan baik. Para dosen membuat media pendidikan yang menarik. Civitas akademika berpenampilan rapi.

f. Hubungan manusiawi (personal interface): Menjunjung tinggi nilai-nilai moral serta profesionalisme, misalnya civitas akademika saling menghormati, baik warga intern maupun ektern sekolah, demokratis, dan menghargai profesionalisme.

g. Mudah penggunaannya (Easy of use). Sarana dan prasarana dipakai, misalnya: aturan-aturan perguruan tinggi mudah diterapkan. Buku-buku perpustakaan mudah dipinjam dan dikembalikan tepat waktu. Penjelasan dosen di kelas mudah 
dimengerti mahasiswa. Contoh soal mudah dipahami. Demonstrasi praktik mudah diterapkan mahasiswa.

h. Bentuk khusus (Feature): Keunggulan tertentu, misalnya perguruan tinggi ada yang unggul dengan hampir semua lulusannya diterima di dunia kerja bermutu. Unggul dengan bahasa Inggrisnya. Unggul dengan penguasaan teknologi informasinya (komputerisasi). Ada yang unggul dengan karya ilmiah kesenian atau olahraga.

i. Standar tertentu (Conformance to specification): Memenuhi standar tertentu, misalnya perguruan tinggi sudah memenuhi Standar Pelayanan Minimal (SPM), perguruan tinggi sudah memenuhi standar ISO 9001:2000.

j. Konsistensi (Consistency): Keajegan, konstan, atau stabil misalnya mutu perguruan tinggi dari dahulu sampai sekarang tidak menurun seperti harus mengatrol nilai para mahasiswanya. Civitas akademika konsisten antara perkataan dengan perbuatan. Apabila berkata tidak berbohong, apabila berjanji ditepati, dan apabila dipercaya tidak mengkhianati.

k. Seragam (Uniformity): Tanpa variasi, tidak tercampur, misalnya perguruan tinggi menyeragamkan pakaian kuliah dan pakaian dinas. Perguruan tinggi melaksanakan aturan, tidak pandang bulu atau pilih kasih.

1. Mampu melayani (Serviceability): Mampu memberikan pelayanan prima, misalnya perguruan tinggi menyediakan kotak saran dan saran-saran yang masuk mampu dipenuhi dengan sebaik-baiknya. Perguruan tinggi mampu memberikan pelayanan primanya kepada pelanggan sehingga semua pelanggan merasa puas.

m. Ketepatan (Accuracy): Ketepatan dalam pelayanan misalnya, perguruan tinggi mampu memberikan pelayanan sesuai dengan yang diinginkan pelanggan, para dosen tidak salah dalam menilai mahasiswanya, semua warga kampus bekerja dengan teliti. Jam kuliah berlangsung tepat waktu. ${ }^{8}$

Dalam penerapannya, seorang pemimpin pada lembaga pendidikan dituntut untuk memiliki suatu self-manajenemen concept yang bisa memahami bahwa kepemimpinan yang diembangnya harus mampu mengarahkan lembaga sebagai suatu lembaga pendidikan yang bermutu dengan indikator-indikator di atas. Dengan self-manajenemen concept, seorang pemimpin dalam kepemimpinannya mampu memahami dirinya sebagai individu

${ }^{8}$ Husaini Usman, Manajemen: Teori, Praktik, dan Riset Pendidikan, (Jakarta: Bumi Aksara, 2006), h. $411-413$ 
sekaligus sebagai pemimpin yang memiliki tanggung jawab pada orang-orang yang dipimpinnya.

\section{KESIMPULAN}

Self-management concept merupakan suatu konsep kepemimpinan yang diperlukan oleh pemimpin pada lembaga pendidikan. Dalam konteks tersebut, self man-management concept mengarahkan seorang pimpinan lembaga pendidikan untuk mengubah sikap, memperbaiki pencitraan diri, terus bekerja dan berkarya, memelihara kesehatan fisik, meningkatkan daya pikiran, mengembangkan kehidupan spiritual, melakukan sesuatu sejak sekarang, konsisten dalam belajar, mengembangkan jaringan, membangun dan memelihara hubungan, serta membangun sesama dengan cara mengembangkan alasan mengapa perlu membangun sesama, memberdayakan sesama serta menciptakan pemimpin, serta membangun kelompok tumbuh bersama sehingga mampu menjamin iklim kondusif dalam lembaga pendidikan.

\section{DAFTAR RUJUKAN}

Ummah, Binti Mudkhiyyatul, Konsep Diri, http://mudkhiya.blogspot.com. (13 Juli 2019)

Prijosaksono, Aribowo dan Marlan Mardianto, 12 Langkah Manajemen Diri, Jakarta : Elex Media Computindo, 2001.

Priyadharma, Triguna, Kreativitas dan Strategi, Jakarta: Golden Trayon Press, 2001.

Munawir, Imam, Asas-Asas Kepemimpinan dalam Islam, Surabaya: Usaha Nasional, tt.

Antonio, Muhammad Syafi'i, Muhammad Saw: The Super Leader, The Super Manager, Jakarta: Tazkia Publishing, 2009.

Nanus, Burt, Terj. Frederik Ruma, Visionary Leadership: Creating a Compelling Sense of Direction for your Organization, Jakarta: PT.Prenhallindo, 2001.

Usman, Husaini, Manajemen: Teori, Praktik, dan Riset Pendidikan, Jakarta: Bumi Aksara, 2006. 